V.V. Nykyforov ${ }^{1}$, Dr. Sc. (Biol.), Prof., orcid.org/0000-0001-8917-2340,

M. S. Malovanyy ${ }^{2}$, Dr. Sc. (Tech.), Prof., orcid.org/0000-0002-3868-1070, I. S. Aftanaziv², Dr. Sc. (Tech.), Prof., orcid.org/0000-0003-3484-7966,

L. I. Shevchuk ${ }^{2}$, Dr. Sc. (Tech.), Assoc. Prof., orcid.org/0000-0001-6274-0256,

L. R. Strutynska ${ }^{2}$, Cand. Sc. (Tech.), Assoc. Prof., orcid.org/0000-0002-0401-5475

\title{
DEVELOPING A TECHNOLOGY FOR TREATING BLUE-GREEN ALGAE BIOMASS USING VIBRO-RESONANCE CAVITATORS
}

Biomass of blue-green algae (cyanobacteria) is an easily accessible and cheap raw material to be converted into biogas. A year's supply of blue-green alga storage in shallow water of the Kremenchuk Reservoir only makes $4.14 \cdot 10^{7}$ tonnes. However, known techniques of "methane digestion" of algae substrate are imperfect because of insufficient level of the product yield, i.e. biogas. This is conditioned by enhanced resistance of the bacterium walls to damage, which decreases the release of intracellular content which is the basis of biomass substrate.

Purpose. Improvement of a technological process of fermentation of blue-green algae, through "methane digestion", as a raw material for production of biogas by homogenisation of algal biomass with cavitation vibro-resonance treatment.

The primary tasks of the research included:

- improvement of a design of an electromagnetic vibro-resonance cavitator so that it can be used for homogenisation of substance of blue-green algae;

- development of the improved process flow schematic of converting blue-green algae biomass into biogas using vibro-resonance cavitators.

Methodology. A complex approach is used which involves combination of analytical and theoretical-and-experimental research on the processes of anaerobic methane digestion. Qualitative composition of biogas produced by cyanobacteria was defined using the methods of spectrum analysis. Studies on dynamics of vibro-cavitators were conducted through methods of the oscillation theory with two degree of freedom systems. Applying approximate methods of the oscillation theory, we defined the optimal parameters of vibro-cavitation homogenisation of water suspense of cyanobacteria.

Findings. Improvement in the technique for converting blue-green algae into biogas is based on additional inclusion of biomass homogenisation block in the process. Homogenisation, i.e. complete release of intracellular content of bacteria, is placed on the operation of cavitational treatment of water suspension of algae with vibro-resonance cavitators of improved design. The vibro cavitator provides cavitational homogenisation of algae suspensions with capacity of $0.75-1.0 \mathrm{~m}^{3} / \mathrm{h}$. The suggested technological process of algae biomass treatment includes three main stages: the stage of algal suspension storage and preparation; the stage of preparation of algae biomass substrate through their homogenisation with vibro-resonance cavitators; the stage of fermentation of biogas through "methane digestion". The product yield, i.e. biogas, increases by 1.4 times due to increasing release of intracellular content of bacteria by vibro-cavitation and reaches $33.0-34.5 \mathrm{~m}^{3}$ of biogas from 1 tonne of the biomass.

Originality. Adding the stage of blue-green algae homogenisation with vibro-resonance cavitators to the standard techniques for their processing with the purpose of increasing the product yield has been suggested by the authors for the first time. This solution provides further biomass substrate fermentation of higher quality increasing the efficiency of biogas generation by over one third. It features academic novelty elements and the design of an electro-magnetic vibro-cavitator of resonance action has been suggested for the first time. Specific shape of its oscillating cavitation agents gives a unique opportunity of qualitative cavitational treatment of liquid substances of higher density and viscosity compared to water. This is exactly what allows establishing a cavitational field in the liquid substance saturated with algae.

Practical value. The value lies in improving the technological process of biogas fermentation from blue-green algae. To implement the cavitational treatment of biomass, an improved design of the vibro-cavitator is suggested taking into account the specific nature of cavitational treatment of liquids with increased density and viscosity. The efficiency of a vibro-cavitator with the crosssectional area of a working camera of 10 inches when processing algae biomass makes $0.75-1.0 \mathrm{~m}^{3} / \mathrm{h}$. This is enough to provide continuous-duty service of a fermentation chamber with the volume of $100 \mathrm{~m}^{3}$ by two vibro-cavitators working alternatively.

Keywords: cyanobacteria, biogas, cavitation, homogenisation, vibro-cavitator, electromagnet

Introduction. Some of the most active fresh water pollutants in the territory of Ukraine are species of the so-called cyanobacteria, which are often called blue-green algae. In our country there are over ten species, the most widespread of which according to the alga system by Parker are those of the kingdom of Prokaryote, division Cyanophycota, class Cyanophyceae. The species of cyanobacteria genus feature a slight difference in structure and size. Depending on the environmental conditions, the life cycle of cyanobacteria lasts from one to a few months, active reproduction occurs through fission, as a matter of fact, at an exponential rate. During the

(C) Nykyforov V. V., Malovanyy M.S., Aftanaziv I. S., Shevchuk L. I., Strutynska L. R., 2019 vegetative season (70-120 days) one initial cell of cyanobacteria can reproduce $10^{20}$ daughter cells, which conditions algal nuisance known as "water-bloom" [1]. The most nutrient medium for their vital activity is warm water saturated with phosphates. During the period of growth, blue-green algae take in carbon dioxide and disengage oxygen. After the vegetative season and dying off, they gravitate to the bottom and their decay, vice versa, is accompanied by active intake of oxygen by decay products. At the same time the efficiency of taking in oxygen far outweighs the efficiency of its production, which results in summer fish and ichthyofauna kill in water bodies accompanied by objectionable odour of the water related to offensive odour of decaying. In autumn-winter seasons when water temperature decreases, cyanobacteria gravitate to the bottom, mix 
with silty mud and, ceasing their reproduction, handle cold winter temperature smoothly. In spring, their activity is renewed, they move up to warm upper waters and propagate themselves actively again. Tranquil flows of shallow waters and winds spread bacterial colonies throughout the water body infesting more and more of its segments. In water-storage reservoirs of hydroelectric power plants and heat power-stations, blue-green algae accumulate mostly on each side of dams where they are brought by winds and water flows. Moreover, the thickness of colonies in the upper layer of the water can make several dozens of centimetres.

The volume of water contaminated by cyanobacteria as well as the numbers of cyanobacteria themselves in water bodies of Ukraine is enormous. Thus, according to the data of research on water of the Kremenchutske Reservoir only with the area of the water table of $2250 \mathrm{~km}^{2}$ with the volume of shallow waters of 828 million $\mathrm{m}^{3}$, with the average density of saturation of water with cyanobacteria of $50 \mathrm{~kg} / \mathrm{m}^{3}$, their overall biomass makes $4.14 \cdot 10^{7}$ tonnes of accumulation throughout the summer vegetative season [2].

At the same time, domestic and foreign researchers have presented solid evidence of the fact that under certain conditions of processing blue-green algae (cyanobacteria), useful raw material for producing biogas as heat-power engineering fuel can be obtained. Thus, [3] studies a method for producing biogas as a result of anaerobic methane digestion of water solution substrate of a fermentation medium and blue-green algae suspension. The attained results accord well with findings described in [4]. The research of the authors in [5] proves that biomass can also be used to produce bioethanol, which can be applied further as raw material for various chemical technology processes.

The process of treating blue-green algae by extracting them from the biomass of lipids, which were further used for conversion into biodiesel, is considered in [6]. In particular, the work analyses the influence of temperature conditions on extraction of lipids from blue-green algae, gives recommendations on choosing the optimal technological parameters of the process of obtaining lipids from the biomass.

The process of biological treatment of blue-green algae biomass is strongly related to the method of biological treatment of the so-called biodegradable wastes, which is common outside Ukraine, namely in Slovakia [7].

One of the problems of applying blue-green algae as a bioenergy raw material is the so-called "seasonality" of accumulation of this biomass in water bodies. Basically, it includes only two warm summer months and the first autumn month. However, in Austria and Germany this problem is successfully solved through growing these algae in special tanks or artificial water bodies. In this way, a year-round operation of biotanks is provided. Another appropriate way to solve the problem of a yearround operation of biotanks for anaerobic methane fermentation of biomass has been proposed by experts from Slovakia [8]. In this country there has been developed use of biotechnologies to produce biogas from the so-called biodegradable wastes.

Therefore, clearing natural water bodies from cyanobacteria is capable of providing two positive aspects - to clear and improve the sanitary conditions of water infested by a hyperactive biological pollutant and to obtain a valuable raw material for bioenergetics and fuel production. Subjecting the cyanobacteria biomass of the Kremenchutske Reservoir to fermentation during methane "digestion", we can obtain 30 million $\mathrm{m}^{3}$ of biogas which, according to its calorific efficiency, is equal to 18.8 million $\mathrm{m}^{3}$ of methane gas, 20 thousand tonnes of oil or 17 thousand tonnes of diesel [2].

Literature review. A great amount of easily accessible and relatively cheap biological raw material, which blue-green algae appeared to be, could not fail to draw attention of specialists in bioenergetics [2]. Experts in the field of converting biological material into fuel for internal combustion engines are also interested in this raw mass [6]. As a result of their research, standard techniques and procedures have been developed to convert blue-green algae into biogas as well as to process them by extracting lipids and fatty acids, which are the basis for producing biodiesel fuel.

The first stages of these technologies are related and include removing blue-green algae from the surface of water bodies, separating them from water in accumulative columns or special tanks and preparing the substrate of algal biomass. To obtain biogas, the substrate is loaded into methane-tanks, where at the temperature of $60{ }^{\circ} \mathrm{C}$ through the method of "methane digestion", there is fermented biogas which is directed to a gas collector. Within the procedure of producing biodiesel fuel, the substrate of biomass is subjected to extraction in order to educe lipids and fatty acids. From this raw material, biodiesel is produced using the conventional technology - etherification of vegetable oils [9]. The product yield in each of these technological processes is limited to a certain extent by the level of homogenisation, i.e. decomposition of raw biomass [10] (blue-green algae), or, elsewise, openness to mass exchange of the biomass localized inside the cellular membrane of a cyanobacterium. The outer membrane of these bacteria is resistant to external influences, which conditions low intensity of processes and synthesis of biogas, and to extraction of lipids [11]. As a result, this does not allow taking full advantage of energetic potential of the biomass.

Unsolved aspects of the problem. In the technological processes of producing biogas from biodegradable wastes [12], which are quite close to the process of blue-green algae treatment, the final stage of "methane" digestion is preceded by the stage of preparing the raw material [12]. In particular, the authors of [13] include mechanical grinding of the raw material followed by its further filtering and mixing with water to prepare suspense at the preparation stage. However, these technological preparation processes are hardly suitable for preparation of water suspense and biomass substrate of blue-green algae. Application of techniques for mechanical disruption of bacterial outer membranes appeared to be ineffective due to their small size. That is why search for more efficient methods for intensification of extracting intracellular content of blue-green algae continues. Quite a powerful method of destructive effect on cyanobacteria is suggested in [14]. The authors studied the use of cavitational phenomena to intensify disruption of membranes and walls of blue-green algae with the purpose of more complete and faster extraction of their intracellular content.

Prior research studies revealed that in the selected samples of blue-green algae, mass volume of lipids made about $1.27 \%$ of the volume of the dry mass of these algae. Experimentally, it was revealed that from this mass it is possible to extract lipids in amount of about $0.32 \%$ of dry mass of the algae. This makes on average $25.2 \%$ of the total amount of lipids which are available in the sample. Such insignificant percentage, which makes only a quarter of the total amount of lipids in the biomass sample under analysis, is explained in the following way. Bacterial cell walls of cyanobacteria appeared to be rather firm and hardly penetrable for extraction. As a result, the intracellular content of bacteria, which is the main source of lipid extraction, is not fully released. Therefore, to increase the percentage of the product yield, i.e. lipids in this case, additional external energetic influence is required to destroy cell walls of cyanobacteria [11].

This is proved by the results of research on the influence of hydrodynamic cavitation activated by a bladed cavitator on the product yield when extracting lipids from cyanobacteria. Ii is determined that application of cavitation increases the volume of lipid extraction up to $0.45 \%$ of the volume of the dry mass. This makes about $35 \%$ of the total volume of the lipids available in the sample. Thus, the use of hydrodynamic cavitation increases the efficiency of the process of extracting lipids from blue-green algae by $10 \%$.

Similar increase in the product yield due to cavitational homogenisation of the blue-green algae biomass was also determined in the technological process of fermentation of biogas through "methane digestion" [11]. Experimentally, it was found that preliminary ultrasonic cavitational treatment of the 
biomass provides the increase in the amount of synthesised biogas by $10-15 \%$, while hydrodynamic bladed cavitational treatment - by $15-20 \%$.

Therefore, homogenisation of the biomass suspense of bluegreen algae through ultrasonic cavitational treatment allowed increasing the product yield, i. e. the efficiency of biogas fermentation by "methane digestion" from $25-26 \mathrm{~m}^{3}$ from one tonne of the biomass to $27.5-28.5 \mathrm{~m}^{3}$, while homogenisation through hydrodynamic bladed cavitational treatment - up to $28.5-30 \mathrm{~m}^{3}$.

The cavitational treatment of water suspense of blue-green algae extensively destroys walls of algae and releases their intracellular content. This occurs due to formation of shock microwaves at collapse of cavitation microbubbles, interchange of pressure and depression zones as well as intensive impact of chemically active oxidation agents of radicals $\mathrm{OH}^{-}$and hydrogen dioxide $\mathrm{O}_{2} \mathrm{H}_{2}^{-}$, which self-generate in the cavitation field, on the membrane and shell of algae. This technique is covered by the useful model patent of Ukraine [15] and it suggests that hydrodynamic cavitation is applied at the stage of "extraction and bio-degradation", which increases the rate of destroying the walls of cyanobacteria by $20-25 \%$ [11]. However, it is obvious that the intended effect was not achieved because of insufficient intensity of the cavitation field formed by bladed cavitators.

Purpose. The purpose of the research is to improve the technological process of fermentation of blue-green algae as a raw material for producing biogas through "methane digestion" applying homogenisation of the algae biomass by vibroresonance cavitation treatment.

The tasks of the research involved:

- experimental research on possibility of applying lowfrequency vibration for homogenisation of the blue-green algae biomass;

- comparative assessment of efficiency of ultrasonic, hydrodynamic bladed and low-frequency vibro-resonance cavitation treatment methods for blue-green algae;

- improvement of the design of the electro-magnetic vibro-resonance cavitator for its use for homogenisation of the blue-green algae substances;

- development of the improved process flow schematic of converting the blue-green algae biomass into biogas using vibro-resonance cavitators.

Results. Scientists of the NU "Lviv Polytechnic" have developed a fundamentally new type of cavitation method which is suitable for productive high quality treatment of water-based liquids including liquids with higher viscosity compared to water. These techniques are united by the common name "vibroresonance cavitators". The advantage of the vibro-resonance cavitators is high efficiency of the cavitation treatment of liquids up to $1.5-1.8 \mathrm{~m}^{3} / \mathrm{h}$. At the same time, they allow processing the liquid both discontinuously and in continuous flow. The characteristic feature of vibro-resonance cavitators is activation of the cavitation field with vibrating deck plates across the cross-section of the flow process chamber. The research on the working experimental models of vibro-resonance cavitators gave evidence of their relevance for efficient cavitation treatment of water suspense of blue-green algae with the purpose of releasing their intracellular content [16]. Based on this data considering specifics of cavitation treatment of suspense of blue-green algae, a process flow schematic of the improved version of the vibro-resonance cavitator for homogenisation of the blue-green algae biomass has been developed.

Fig. 1 shows the schematic diagram of the vibro-resonance cavitator, which can be used for homogenisation of the cyanobacteria biomass due to the improved construction design of its cavitation initiators. The main constructive units of this vibrocavitator are pipeline 6 to supply the water suspense of processed biomass, operation chamber 9 and pipeline 14 for processed liquid removal. Flexible corrugated pipes 8 and 12, which connect the operation chamber 9 with the pipelines 6 and 14 , allow the operation chamber to move spatially along its geometrical axis. On the pipelines 6 and 14 there are set immovable reaction masses 11 , in which driving electromagnets of oscillating movements of the operation chamber are fixed on cases 4 . The electric drive contains circular stator 15 and coil 3 . On the operation chamber 9 there is installed a ring armature 10. The operation chamber 9 coupled with the ring armature 10 due to corbel-pieces 2 and pins 5 is springily set up on the reaction masses 11. Fixed on the pipelines of supply and diversion of the processed water, circular stators 15 with windings 3 together with the ring armature 10 placed between them form electromagnetic drive of the vibro-cavitator. The magnet windings are connected to the mains with phase displacement. This provides alternating dragging of the ring armature 10 with the operation chamber 9 to the left and to the right electromagnet. Therefore, tentative movements of the operation chamber 9 are provided lengthwise its geometrical axis with a frequency exceeding the frequency of electrical network twofold. At the standard frequency of electrical network of $50 \mathrm{~Hz}$, the oscillation frequency of the operation chamber makes $100 \mathrm{~Hz}$.

Inside the operation chamber 9 , a deck plate 7 is rigidly fixed; its surface is perforated with holes for flowing of the liquid processed. During the treatment of liquid, the deck plate 7 oscillates along with the operation chamber 9, i. e. it acts as an oscillatory deck plate. Similar, yet immobile, deck plates 13 are attached to the pipelines of supply and diversion of the liquid. A protective cover 1 protects moving elements of the vibro-cavitator from intrusion of foreign objects.

The operation concept of this electromagnetic vibro-cavitator is described in detail in the useful model patent of Ukraine No. 107769 [16].

However, in this version, this vibro-cavitator will not provide the proper quality of treatment of water suspense of the cyanobacteria biomass. This is conditioned by the fact that cavitation agents, which are present in oscillatory 7 and immobile 13 deck plates as tapered holes, will be silted with bacteria. This will rapidly decrease the intensity of the cavitation field

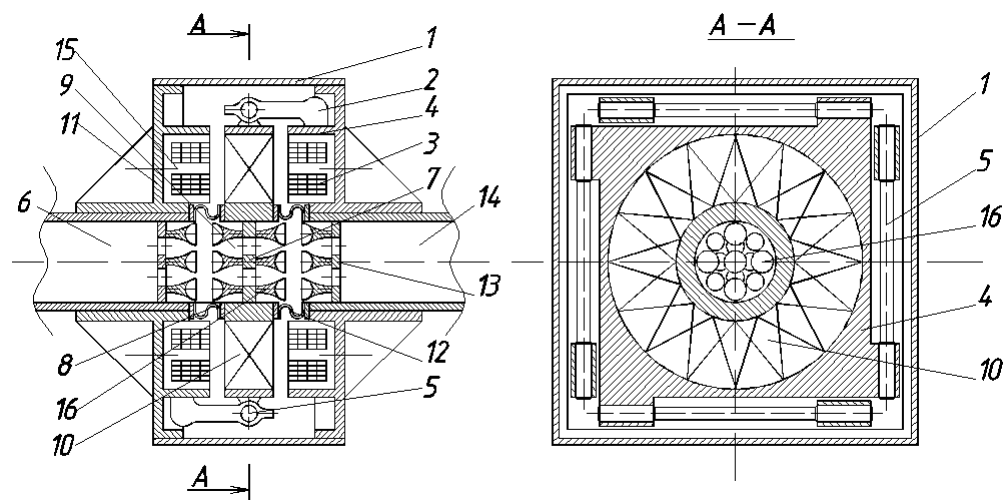

Fig. 1. Schematic diagram of the improved vibro-resonance cavitator with electromagnetic drive for homogenisation of blue-green algae biomass 
and, respectively, the quality of homogenisation of cyanobacteria. To eliminate this drawback, on the oscillatory deck plate 7 and immobile deck plates 13 fixed on the pipelines there are installed special cavitation agents 16 facing one another with their end faces. The outer surface of the cavitation agents is in the form of a hyperboloid of revolution, while the end surface is given the form of a hemisphere inscribed in a hyperboloid with the radius which is equal to double swing amplitude of the oscillatory deck plate 7 . The minimum distance between the adjacent cavitation agents 16 situated on the shared deck plate is equal to the oscillation amplitude of the deck plate 7 , while the minimum distance between oscillatory and immobile cavitation agents 16 is equal to swing amplitude of the deck plate 7. Fig. 2 shows flow of processed water suspense around cyanobacteria biomass of the cavitation agents 16 and formation of a cavitation field at harmonic oscillations of the operation chamber.

In the course of motion of the oscillatory deck plate 7 from one immobile deck plate to another 13 (opposite), the processed liquid at a high speed flows around the outer hyperboloid surface of those cavitation agents 16 which are moving away from the immobile deck plate 13 . Having gone round the outer surface of the moving cavitation agents 16 , the processed liquid swirls into their inner spherical recess (Fig. 2). At the recommended oscillation amplitude of the deck plate $A=(1.5-$ 2.0) $\mathrm{mm}$ and frequency of $100 \mathrm{~Hz}$, the speed at which the processed liquid flows around the outer surface and swirls into their inner spherical recess of the cavitation agents 16 makes approximately $(1.4-2.0) \mathrm{m} / \mathrm{s}$. Due to the increase in the pressure, liquid jets lose their density; going round the cavitation agents liquid streams swirl into their inner spherical recesses and turn from laminar flows into turbulent flows. At the same time, from the air and gases dissolved in water behind the spherical recess in the cavitation agents 16 there are formed cavitation cavities.

Our laboratory studies revealed that the efficiency of cavitation treatment of blue-green algae increases when supplying gas to the cavitation zone of the operation 9. This is conditioned by the additionally supplied gas compensating for the phenomenon of degassing of the processed liquid in the cavitation field as well as by a possibility of formation of additional oxidizing radicals destroying the walls of bacteria provided the gas is available. Oxygen and cheaper nitrogen appeared to be the most efficient during the cavitation treatment of bluegreen algae. Formed in the cavitation field, the radicals of the former demonstrate high oxidation capacity, while the radicals of the latter - increased chemical activity. All these newly formed compounds in the cavitation field activate corrosion and destruction of the walls of blue-green algae, whereas highfrequency micro-shocks from the collapse of cavitation microbubbles complete the destructive processes successfully. The amount of gas flow within the range of $(0.15-0.25) \mathrm{m}^{3}$ per cubic meter of the processed substrate appeared to be efficient.

When designing electromagnetic vibro-resonance cavitators, one relies on specific efficiency of the cavitation treatment of water suspense and technological duration of cavitation treatment of a portion of the liquid filling up the operation chamber 9. Discrete (batchwise) or continuous nature of the treatment of liquid is also taken into account. From these considerations, the volume of the operation chamber and diame-

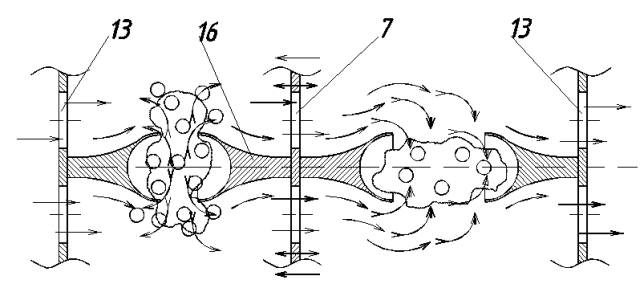

Fig. 2. The scheme of formation of the cavitation field at low frequency harmonic oscillations of the cavitation agents (the numbers of positions are borrowed from Fig. 1) ters of pipelines of supply and diversion of the processed liquid are calculated and specified.

Calculation of elasticity of oscillating systems (cylindrical rods 5) of the power of the drive electromagnets and their structural elements (the shape and size of the electromagnetic iron, the cross-section and the number of turns of the winding, etc.) is done according to the methods for the calculation of vibration machines with electromagnetic drive. Efficient work of vibro-resonance cavitators as well as that of cavitators of other types and operating principle is based on energy impact on the liquid environment, which is accompanied by loss of strength of intermolecular bonds of liquid and self-perturbation of specific cavitation phenomena in it.

The efficiency of application of the vibro-resonance cavitator of the suggested design for homogenisation of blue-green algae biomass, which is accompanied by destruction of its membrane and release of the intracellular content, was tested on the working model of a vibro-cavitator. Fig. 3 shows a photograph of the working model of a vibro-cavitator for homogenisation of blue-green algae biomass with a control panel for the power supply network.

The main constituent elements of the working model of a vibro-cavitator are a cylindrical operation chamber with the volume of $1 \mathrm{dm}^{3}$, a system to supply blue-green algae substrate and gas to it, an electromagnetic vibration motor with an oscillatory deck plate attached to it along with cavitation agents and power supply network of the vibration motor.

The cavitator fixed on the immovable foundation consists of two parallel tubes vertically arranged one on the other, which are connected with a metal ring. The connecting metal ring is equipped with branch pipes for supplying the treated liquid and concurrent gases as well as a nozzle for fastening the manometer which lock pressure in the operating space of the cavitator. Above the cavitator on the immovable platform there is fixed an electromagnetic vibration motor of the cavitator, which consists of an electromagnet placed in the housing along with the winding coil and an oscillating armature mounted on the resilient elements. A rod, whose loose end is guided inward the cavitator, is attached to the armature.

The moving deck plate along with cavitation agents attached to it is rigidly fixed to the rod guided inward the cavitator. The shape of the cavitation agents corresponds to the shape of the agents described above, presented in Figs. 1 and 2. Below the moving deck plate on a plate attached to the bottom

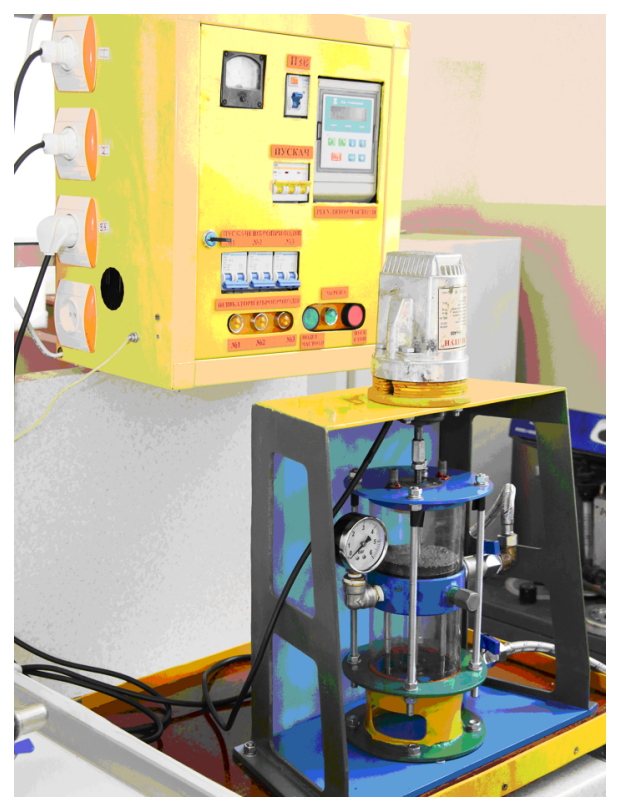

Fig. 3. The photograph of the working model of a vibro-cavitator for homogenisation of blue-green algae biomass with a control panel for the power supply network 
of the cavitator an immobile deck plate is positioned together with cavitation agents reverted with their end surface to the moving deck plate agents. Apart from cavitation agents, openings for the flow of the treated fluid are applied to equip the moving and immobile deck plates.

The electric control network for electromagnetic drive of the vibro-cavitator is equipped with a laboratory autotransformer in order to control electromagnets power supply as well as with a wattmeter to record its energy input.

The programme of experimental research on the efficiency of vibro-resonance cavitation treatment of blue-green algae substrate required a number of stages:

- at the first stage, optimal conditions for vibrational modes of cavitation agents were defined;

- at the second stage, rational duration of cavitation treatment of water suspense of blue-green algae was established;

- at the third stage, the impact of types and volumes of the gas suppled to the cavitator on the efficiency of cavitation treatment of blue-green algae was studied.

The purpose of the first stage studies was to establish optimal parameters of the power supply of the vibration motor electromagnet at which the highest intensity of spatial displacements of the cavitation agents is provided at a minimum level of energy consumption as well as the highest intensity of the cavitation field in water suspense of blue-green algae. In this regard, the cavitator war filled to 0.75 of its volume full with water suspense of blue-green algae in 1:1 ratio of the water volume to the volume of the substrate of blue-green algae. Given definite and constant oscillation amplitude of the deck plate with cavitation agents, for example, $A=2 \mathrm{~mm}$, changing electric drive power supply within the range of $25-100 \mathrm{~Hz}$ with a frequency controller, we measured the power value of electricity consumption after every other $2.5 \mathrm{~Hz}$. Stability of oscillation amplitude of the deck plate with cavitation agents was achieved by regulating the magnitude of the power current of the electromagnet coil winding with the autotransformer.

It was established that minimum power consumption of the vibration motor at the cavitation treatment of blue-green algae using the vibro-cavitator under analysis is observed for the oscillation amplitude $A=2 \mathrm{~mm}$ at the frequency of power supply voltage $f=37 \mathrm{~Hz}$, at which the moving deck plate oscillates with the frequency $f_{d}=74 \mathrm{~Hz}$. This frequency for the oscillating system of this vibration motor coincides with its own frequency, i. e. when the oscillating system operates in a mode close to the resonance.

At the second stage, the rational duration of cavitation treatment of blue-green algae was determined. For this purpose, the cavitation treatment of blue-green algae was performed at the oscillation frequency of the deck plate with cavitation agents being $f_{d}=37 \mathrm{~Hz}$, and the amplitude $A=2 \mathrm{~mm}$ during different periods of time from 1 minute to 10 minutes. Ultimate efficiency of the treatment was the controlled variable and it was assessed according to the amount of the biogas obtained from algae substrate through cavitation treatment. Biogas was produced as a result of fermentation of the biomass of blue-green algae samples applying the laboratory test facility for "methane digestion"; for fermentation anaerobic microorganisms were used.

It was found that with increasing duration of the cavitation treatment of suspense of blue-green algae, the amount of biogas obtained as a result of their anaerobic fermentation increases as well, asymptotically approaching certain values which depend on algae concentration. At the same time, within the first 4-5 minutes of the cavitation treatment the rate of increase in biogas output is quite high, whereas within the last 4-5 minutes it decreases significantly. Thus, within the first 5 minutes of the treatment, the volume gain of the biogas obtained increased ever minute reaching the value of $24 \mathrm{dm}^{3}$ out of $0.75 \mathrm{dm}^{3}$ of the processed suspense of the algae treated cavitationally. Another 5 minutes which followed increased gas output by $10-15 \%$ only. This allows considering the duration within 4.5-5.0 minutes to be the efficient duration of vibro- cavitation treatment of suspense of blue-green algae provided the above cavitation parameters $\left(f_{d}=37 \mathrm{~Hz}, A=2 \mathrm{~mm}\right)$.

At the third stage, the impact of the gas supplied to the operating space of the vibro-cavitator on the efficiency and duration of cavitation treatment of blue-green algae was studied. For this purpose, gases, namely, oxygen and nitrogen were supplied to the operating space of the vibro-cavitator with the flowrate of $0.15-0.2 \mathrm{dm}^{3}$ per $1 \mathrm{dm}^{3}$ of the treated suspense. It was established that the supply of gases to the zone of the cavitation treatment increases the gas output out of the substrate on average by $5-10 \%$. Moreover, the optimal duration of the cavitation treatment decreases from 5 minutes to 4 minutes. The efficiency of oxygen supply appeared to be higher than that of nitrogen by $15-20 \%$ only. However, considering the high cost of oxygen and significant volumes of the biomass to be treated under production conditions, it becomes obvious that it is reasonable to focus on cheaper nitrogen.

Therefore, the experimental research on vibro-cavitation treatment of water suspense of blue-green algae proved that due to increasing the intensity of the formed cavitation field, this method for algae homogenisation is by $10-15 \%$ more efficient than the bladed hydrodynamic method and by 15-20\% more efficient than the ultrasonic cavitational treatment. Moreover, it was revealed that the supply of the gas relating to the cavitation treatment to the operating space of the vibrocavitator increases the product yield by $5-10 \%$. Of the two gases under study, namely, oxygen and nitrogen, the supply of oxygen appeared to be more efficient with the flowrate of $0.15-0.20 \mathrm{dm}^{3}$ of the gas per $0.75 \mathrm{dm}^{3}$ of the substance treated. The optimal duration of the cavitation treatment of blue-green algae has also been determined. For the vibro-cavitator model under studies, it makes approximately $4-4.5$ minutes at the oscillation amplitude of cavitator agents $A=2 \mathrm{~mm}$ and frequency $f_{d}=74 \mathrm{~Hz}$.

Summarising the results of the experimental research, we can note the following. First of all, it was experimentally proved that pre-treatment of the blue-green algae biomass increases the product yield, i.e. obtaining biogas after fermentation by "methane digestion". At the initial reference values of the product yield (biogas) in equivalent of 1 tonne of the biomass within $25 \mathrm{~m}^{3}$ of the biogas [14], application of biomass homogenisation through the cavitation treatment in the technological process of cyanobacteria biomass preparation increases the volume of generated biogas by 1.4 times. Moreover, the ultrasonic cavitational treatment of the biomass according to the results in [11] increases the product yield (biogas) by $10-15 \%$, which in equivalent makes $27.5-28.75 \mathrm{~m}^{3}$ of biogas out of 1 tonne of raw material. The hydrodynamic bladed cavitation treatment of the biomass increases the volume biogas output up to $28.5-30 \mathrm{~m}^{3}$, i. e. by $15-20 \%$ more compared to fermentation of raw material without its pre-treatment [11].

Vibro-resonance cavitation pre-treatment of blue-green algae biomass by homogenisation appeared to be the most efficient. Provided optimal technological parameters with the oscillation amplitude of cavitation agents $A=2 \mathrm{~mm}$, oscillation frequency $f=74 \mathrm{~Hz}$ and supply of gas (oxygen or nitrogen) to the operation chamber of the vibro-cavitator, ensured product yield amounts $33.0-34.5 \mathrm{~m}^{3}$. This exceeds the product yield obtained at conventional methods of "methane digestion" without homogenisation cavitation treatment of algae biomass by 1.4 times. The fact that the volume of the product yield (biogas) with the vibro-cavitation pre-treatment of the biomass exceeds this factor with the hydrodynamic treatment by $10-15 \%$ and ultrasonic cavitational treatment by $15-20 \%$ can be easily explained. The ultrasonic cavitational treatment provides high intensity level of the cavitation field only in the section where a magnetostricter is immersed in liquid, i.e. it is characterised by a "point" source of cavitation activation. When moving away from the magnetostricter, the cavitation field decreases its intensity rapidly, which does not provide proper destructive effect on cyanobacteria walls. 
In steady-state operation of the bladed hydrodynamic cavitator, the treated liquid in the operation chamber is whirled by blades up to the speed which is commensurate with the traverse speed of the blades themselves. At the same time, relative moment speed of the blades and liquid decreases, which also reduces the intensity of the formed cavitation field. Vibro-resonance cavitators do not have these drawbacks.

Based on the data of the experiment research on vibroresonance cavitation treatment of blue-green algae suspense taking into account design capabilities and features of the developed design of an industrial vibro-cavitator, an improved process flow diagram of the process of converting blue-green algae suspense into biogas is suggested. This flow diagram is shown in Fig. 4 and includes three main blocks.

The diagram provides three main blocks, in particular: Block I is a block of storing raw material and preparing bluegreen algae suspense; Block II - a block of vibro-resonance homogenisation of algae suspense; Block III - a block of fermentation of biogas through anaerobic "methane digestion". Consequently, the treatment of raw material is conducted in three stages. At the first stage, blue-green algae, which has been removed from open water bodies or grown in water baths-reservoirs, are poured along with water into storage-sediment chambers (Position 1 in Fig. 4). After 25-30 minute sedimentation, the blue-green algae, whose specific weight is less than that of water, detach from water, i.e. they rise to the upper part of the storage while water settles to the bottom. The water from the storage is poured into a water body or baths-reservoirs for growing raw materials, whereas ready-made water suspense of blue-green algae is supplied to the block of vibro-cavitation homogenisation using pumps. Here, 2-3 industrial vibro-resonance cavitators are installed. Apart from the cavitators, Block II includes a substation 3 supplying gas to the cavitators and regulating equipment 4 of changing over the flows of the treated suspense between the cavitators using pneumatic slide valves 5 .

After cavitation treatment, the biomass of the treated bluegreen algae homogenised in the cavitators is supplied to an intermediate storage unit 6 where it is disengaged from extra water. The filtered water is poured into a sediment chamber 7 , while the prepared biomass substrate goes to Block III into a fermentation chamber 8 for converting it into biogas. Along with the algae biomass, anaerobic bacteria are supplied into the chamber 8 from a bio-substation 9; they ferment biogas absorbing the algae biomass. To accelerate the process, the biomass loaded into the fermentation chamber is heated up to temperature of $60{ }^{\circ} \mathrm{C}$. From the fermentation chamber, the

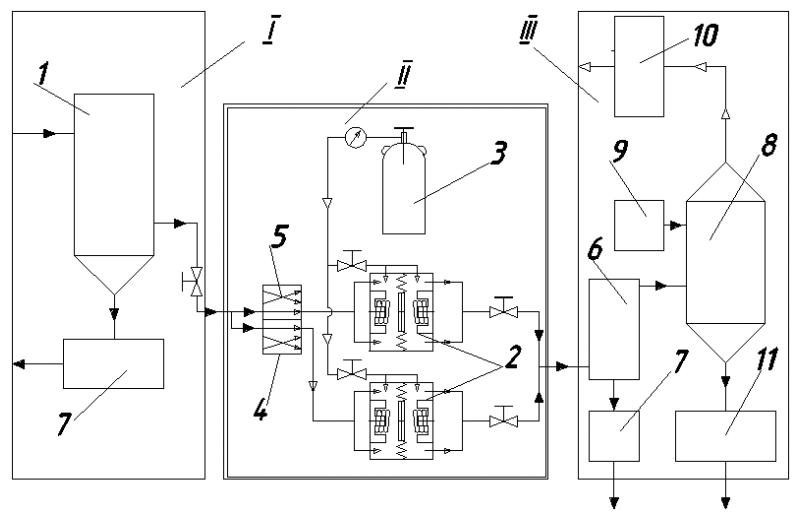

Fig. 4. Schematic diagram of the process of converting bluegreen algae into biogas thorough vibro-cavitation homogenisation of biomass:

1 - raw material storage; 2 - vibro-resonance cavitators; 3 - gas supply substation; 4 - regulating electrical equipment; 5 - pneumatic slide valve switch of liquid flow; 6 - intermediate storage unit; 7 - sediment chamber; 8 - fermentation chamber; 9 - biosubstation of anaerobic bacteria; 10 - gas storage substation; 11 storage unit for treated raw material generated biogas is pumped out to a gas substation 10 where it fills special reservoirs and containers for further use. The worked-out gas fermentation products are removed from the chamber 8 and directed to a special storage unit 11 for further conversion into organic fertilizers for plant nutrition. Therefore, non-wastefulness of the technological process of treatment of blue-green algae is provided.

Taking into account the duration of the gas fermentation process, which lasts for a few tens of days, it can be noted that in order to ensure regular operation of one fermentation chamber with a volume of $100 \mathrm{~m}^{3}$, it is enough to apply two alternating vibro-cavitators of the design described above with a crosssection area of the working chamber of 10 inches.

Generated gas is mainly used as fuel for heating water of heating systems of greenhouse facilities or household and industrial premises. Taking into account sufficiently high calorific efficiency of biogas, which comes short of this parameter of natural gas methane by $15-20 \%$, biogas can be successfully employed for bioenergetics as well.

The difference of the suggested technological process of converting blue-green algae into biogas from conventional unit processes is in additional installation of Block II of cavitation homogenisation of biomass in it. Naturally, its installation, functioning and maintenance require additional costs. However, increase in the product yield, i. e. biogas, by $35-40 \%$ at considerable volumes of algae treatment not only covers the costs for installation and functioning of the block of cavitation homogenisation of raw material, but will also provide extra revenue.

The capability of destroying cyanobacteria walls, which is accompanied by release of intracellular content and complete destruction, allows applying vibro-cavitators successfully for decontaminating water of ponds of fish breeding farms from biological pollution, in particular, of small and shallow reservoirs for nursery (fry) culture. They are also suitable for purification of water from biological and organic pollution in small reservoirs for public use, including swimming pools, ponds, lakes, etc. In this case, a cleaning substation equipped with vibro-cavitators with their operation control panel is set up on the bank of a water body. Water is supplied by pumps to the vibro-cavitators in the operation chambers of which organic pollutants are oxidized and walls of bacterial cells are destroyed. After short-term settling, the water is returned to a water body, while the settled silty mud is converted into organic fertilizers for plant nutrition.

Therefore, it can be noted that the results of the given research fully relate to two significant aspects of humanity. First of all, this is improvement of environmental ecology due to destruction of active pollutants of natural water, which cyanobacteria are. At the same time, an important area of the electric-power industry is improved; this is bioenergy, which is based on application of renewable energy sources, which blue-green algae are.

The research findings also contribute to enhancing the sphere of industrial use of cavitation. The specific form of vibrational cavitation agents in the suggested design of a vibrocavitator makes it possible to use them successfully for cavitational decontamination of water liquids with higher density and viscosity, compared to water, from biological pollutants. This opens the prospect of successful use of theses vibro-cavitators for purification of water from organic and biological pollution of industrial waste effluents of higher density and viscosity of enterprises of refining and food processing industries, for example, brewing enterprises, yeast-production companies, etc.

\section{Conclusions.}

1. It was experimentally established that homogenisation of blue-green algae (cyanobacteria) biomass through their cavitation treatment due to the destructive effect of cavitation on bacterial walls and fuller release of intracellular content of bacteria promotes the increase in the product yield (biogas) volume by $35-40 \%$ in the technical fermentation process through "methane digestion" enhancing the fermentation of biogas from 1 tonne of biomass substrate from 25 to $34.5 \mathrm{~m}^{3}$. 
2. Among various conventional methods for cavitation treatment of liquids for algae, the vibro-resonance cavitation treatment appeared to be the most efficient at the oscillation amplitude of cavitation agents $A=2 \mathrm{~mm}$ and frequency $f=74 \mathrm{~Hz}$. This treatment increases biogas fermentation by 1.35-1.4 times, which exceeds the product yield (biogas) by $10-15 \%$ when using hydrodynamic bladed cavitation and by $15-20 \%$ when using ultrasonic cavitation treatment for homogenisation.

3. Improvement of the design of low frequency vibro-resonance cavitators through equipping their oscillatory elements with cavitation agents of a particular structure not only provided increase in their efficiency up to $1.0-1.5 \mathrm{~m}^{3} / \mathrm{h}$, but also enhanced biogas fermentation from 1 tonne up to $33.0-34.5 \mathrm{~m}^{3}$ (by 35-40\%) due to improved quality of blue-green algae biomass homogenisation.

4. The improved process flow schematic of fermentation conversion of blue-green algae into biogas includes three main blocks, namely: a block of storing and preparing blue-green algae water suspense, a block of blue-green algae biomass homogenisation by vibro-cavitators and a block of fermentation of biogas through "methane digestion". In this case, the product yield, i. e. biogas, from 1 tonne of the blue-green algae biomass increases up to $34.5 \mathrm{~m}^{3}$ due to vibro-cavitation homogenisation, which is equal to 0.7 tonne of oil and 0.6 tonne of diesel fuel by calorific efficiency and exceeds these factors at biogas fermentation without applying cavitation homogenisation by $40 \%$.

\section{References.}

1. Nguyen-Quang, T., Lieou, K.-C., Hushchyna, K., Nguyen, T.-D., Mood, N.Sh., Nadeem, M., ... \& Hirtle, R. (2016). The first step to sketch the spatio-temporal evolution of biochemical and physical parameters involving in the harmful algal blooms (hab) in mattatall lake (Nova Scotia, Canada). Environmental problems, 1(1), 1-18.

2. Malyovanyy, M.S., Nikiforov, V.V., Kharlamova, O.V., \& Sinelnikov, O. D. (2016). Reduction of the environmental threat from uncontrolled development of cyanobacteria in the waters of the Dnieper reservoirs. Environmental problems, 1(1), 61-64. 3. Milledge, J. J., \& Heaven, S. (2017). Energy Balance of Biogas Production from Microalgae: Effect of Harvesting Method, Multiple Raceways, Scale of Plant and Combined Heat and Power Generation. Journal of Marine Science and Engineering, 5, 9-15. https://doi.org/10.3390/jmse5010009.

4. Milledge, J. J., Nielsen, B. V., Maneein, S., \& Harvey, PJ. (2019). A Brief Review of Anaerobic Digestion of Algae for Bioenergy. Energies, 12(6):1166, 1-22. https://doi.org/10.3390/en12061166.

5. Jesús Velazquez-Lucio, Rosa M. Rodríguez-Jasso, Luciane M. Colla, Aide Sáenz-Galindo, Daniela E. CervantesCisneros, Cristóbal N. Aguilar, ... \& Héctor A. Ruiz (2018). Microalgal biomass pretreatment for bioethanol production: a review. Biofuel Research Journal, 17, 780-791. https://doi. org/10.18331/BRJ2018.5.1.5.

6. Hielscher Ultrasound Technology (n.d.). Biodiesel from Algae using Ultrasonication. Retrieved from https://www.hielscher.com/algae extraction 01.htm.

7. Hutňan, M., \& Bodík, I. (2015). Biogas production from biodegradable wastes. Upravlinnia vidkhodamy, 2015/07, Retrieved from http://www.energie-portal.sk/Dokument/produkcia-bioplynu-z-biologicky-rozlozitelnych-odpadov-102475.aspx > .

8. Hutňan, M., \& Bodík, I. (2015). Biogas plants and biodegradable wastes. A chance for biodegradable wastes? Waste Management, 2015/07, Retrieved from http://www.odpadyportal.sk/Dokument/102502/co-by-vam-nemalo-ujst-odpadovehospodarstvo-201507.aspx.

9. Raheem, A., Prinsen, P., Vuppaladadiyam, A. K., Zhao, M., \& Luque, R. (2018). A review on sustainable microalgae based biofuel and bioenergy production: Recent developments. Journal of Cleaner Production, 181, 42-59. https://doi. org/10.1016/j.jclepro.2018.01.125.
10. Greenly, J. M., \& Tester, J.W. (2015). Ultrasonic cavitation for disruption of microalgae. Bioresource Technology, 184, 276-279. https://doi.org/10.1016/j.biortech.2014.11.036.

11. Malovanyy, M., Nikiforov, V., Kharlamova, O., \& Synelnikov, O. (2016) Production of renewable energy resources via complex treatment of cyanobacteria biomass. Chemistry \&amp; Chemical Technology, 10(2), 251-254.

12. Janiš, S. (2014). End of biogas in Slovakia? Bratislava. Retrieved from http://www.oenergetike.sk/oze/bioplyn-na-slovensku-DEFINITIVNYKONIEC/>.

13. Janiš, S. (2014). Biogas in Slovakia, the ultimate end? Retrieved from http://www.oenergetike.sk/oze/bioplyn-na-slovensku-definitivny-koniec/>.

14. Ros, P., Silva, C., Silva-Stenico, M., Fiore, M., \& Castro, H. (2013). Assessment of chemical and physicochemical properties of cyanobacterial lipids for biodiesel production. Marine Drugs, 11(7), 2365-2381. https://doi.org/10.3390/md11072365.

15. Malovanyy, M.S., Nykyforov, V.V., \& Kharlamova, O.V. (2016). Method for obtaining biogas from blue-green algae. Patent No. 105896, Ukraine.

16. Aftanaziv, I. S., Strohan, O.I., Shevchuk, L.I., \& Starchevskyi, V. L. (2014). Vibrational electromagnetic cavitator. Patent No. 107769, Ukraine.

\section{Розробка технології переробки біомаси синьо-зелених водоростей із використанням віброрезонансних кавітаторів}

\author{
В. В. Никифоров ${ }^{1}$, М. С. Мальований ${ }^{2}$,
} І. С. Афтаназів ${ }^{2}$, Л. І. Шевчук ${ }^{2}$, Л. Р. Струтинська ${ }^{2}$

1 - Кременчуцький національний університет імені М. Остроградського, м. Кременчук, Україна

2 - Національний університет „Львівська політехніка“, м. Львів, Україна, е-mail: ivan.aftanaziv@gmail.com

Біомаса синьо-зелених водоростей (ціанобактерій) легкодоступна й дешева сировина для переробки на біогаз. Річні запаси накопичення синьо-зелених водоростей на мілководдях лише Кременчуцького водосховища сягають $4,14 \cdot 10^{7}$ тон. Однак відомі технології „,метанового бродіння" субстрату водоростей недосконалі через недостатній рівень виходу готового продукту, тобто біогазу. Це обумовлено підвищеною стійкістю стінок цих бактерій до руйнування, що знижує вивільнення їх внутріклітинного вмісту, який і є основою субстрату біомаси.

Мета. Удосконалення технологічного процесу ферментації синьо-зелених водоростей як сировини для виготовлення, „метановим бродінням“, біогазу шляхом гомогенізації біомаси водоростей віброрезонансною кавітаційною обробкою.

У основні задачі дослідження входили:

- удосконалення конструкції електромагнітного віброрезонансного кавітатора задля його придатності для гомогенізації субстанцій синьо-зелених водоростей;

- розробка вдосконаленої принципової технологічної схеми переробки біомаси синьо-зелених водоростей на біогаз із використанням віброрезонансних кавітаторів.

Методика. Застосовано комплексний підхід, що включає поєднання аналітичних і теоретико-експериментальних досліджень процесів анаеробного метанового бродіння. Якісний вміст продукованого ціанобактеріями біогазу визначали із використанням методики спектрального аналізу. Дослідження динаміки віброкавітатора здійснювали методами теорії коливань систем із двома ступенями вільності. Із використанням наближених методів теорії коливань визначені оптимальні параметри віброкавітаційної гомогенізації водної суспензії ціанобактерій.

Результати. До основи вдосконалення технології переробки сиьо-зелених водоростей у біогаз покладемо додаткове включення до процесу блоку гомогенізації біомаси. Го- 
могенізація, тобто повне виділення внутріклітинного вмісту бактерій, покладена на операцію кавітаційної обробки водяної суспензії водоростей віброрезонансними кавітаторами вдосконаленої конструкції. Віброкавітатор забезпечує кавітаційну гомогенізацію суспензій водоростей із продуктивністю $0,75-1,0 \mathrm{~m}^{3} /$ год. Запропонований технологічний процес переробки біомаси водоростей включає три основні етапи: етап накопичення й підготовки суспензії; етап підготовки субстрату біомаси водоростей та їх гомогенізацією віброрезонансними кавітаторами; етап ферментації біогазу „метановим бродінням“. Вихід готового продукту, тобто біогазу, при цьому, завдяки збільшенню віброкавітацією виділення із бактерій їх внутріклітинного вмісту, збільшується в 1,4 рази і сягає $33,0-34,5 \mathrm{~m}^{3}$ біогазу із 1 тони біомаси.

Наукова новизна. Доповнення типових технологічних процесів переробки синьо-зелених водоростей етапом їх гомогенізації віброкавітацією з кінцевою метою підвищення виходу готового продукту авторами запропоновано вперше. Це рішення забезпечує більш якісну подальшу ферментацію субстрату біомаси з підвищенням більш ніж на третину продуктивності утворення біогазу. Має елементами наукової новизни й уперше запропонована конструкція електромагнітного віброкавітатора резонансної дії. Специфічна форма його коливних збурювачів кавітації надає унікальну можливість якісної кавітаційної обробки рідинних субстанцій підвищеної, порівняно з водою, густини й в'язкості. Саме це й дозволяє збурювати кавітаційне поле високої інтенсивності в насиченій водоростями рідинній субстанції.

Практична значимість. Полягає у вдосконаленні технологічного процесу ферментації біогазу із синьо-зелених водоростей. Для реалізації кавітаційної обробки біомаси запропонована вдосконалена конструкція віброкавітатора з урахуванням специфіки кавітаційної обробки рідин підвищених густини та в'язкості. Продуктивність віброкавітатора з поперечним перерізом робочої камери 10 дюймів при обробці біомаси становить $0,75-1,0$ м³ $/$ год. Цього достатньо для забезпечення двома почергово працюючими віброкавітаторами безперебійної роботи ферментаційної камери об'ємом $100 \mathrm{~m}^{3}$.

Ключові слова: ціанобактерії, біогаз, кавітація, гомогенізація, віброкавітатор, електромагніт

\section{Разработка технологии переработки биомассы сине-зеленых водорослей с использованием виброрезонансных кавитаторов}

\section{В. В. Никифоров ${ }^{1}$, М. С. Мальованый ${ }^{2}$, И. С. Афтаназив ${ }^{2}$, Л. И. Шевчук ${ }^{2}$, Л. Р. Струтинская ${ }^{2}$ 1 - Кременчугский национальный университет имени М. Остроградского, г. Кременчуг, Украина \\ 2 - Национальный университет „Львовская политехни- ка“, г. Львов, Украина, e-mail: ivan.aftanaziv@gmail.com}

Биомасса сине-зеленых водорослей (цианобактерий) - легкодоступное и дешевое сырье для переработки в биогаз. Годовые запасы накопления сине-зеленых водорослей на мелководьях только Кременчугского водохранилища составляют $4,14 \cdot 10^{7}$ тонн. Однако известные технологии „метанового брожения“ субстрата водорослей несовершенны из-за недостаточного уровня выхода готового продукта, т. е. биогаза. Это обусловлено повышенной устойчивостью стенок этих бактерий к разрушению, что снижает высвобождение их внутриклеточного содержимого, который и является основой субстрата биомассы.

Цель. Совершенствование технологического процесса ферментации сине-зеленых водорослей как сырья для производства, „метановым брожением“, биогаза путем гомогенизации биомассы водорослей виброрезонансной кавитационной обработкой.
В основные задачи исследования входили:

- совершенствование конструкции электромагнитного виброрезонансного кавитатора для его пригодности для гомогенизации субстанции сине-зеленых водорослей;

- разработка усовершенствованной принципиальной технологической схемы переработки биомассы сине-зеленых водорослей в биогаз с использованием виброрезонансних кавитаторов.

Методика. Использован комплексный подход, включающий сочетание аналитических и теоретико-экспериментальных исследований процессов анаэробного метанового брожения. Качественный состав производимого цианобактериями биогаза определяли с использованием методики спектрального анализа. Исследование динамики виброкавитаторов осуществляли методами теории колебаний систем с двумя степенями свободы. С использованием приближенных методов теории колебаний определены оптимальные параметры виброкавитационной гомогенизации водной суспензии цианобактерий.

Результаты. В основу совершенствования технологии переработки сине-зеленых водорослей в биогаз положено дополнительное включение в процесс блока гомогенизации биомассы. Гомогенизация, то есть полное выделение внутриклеточного содержимого бактерий, возложена на операцию кавитационной обработки водной суспензии водорослей виброрезонансными кавитаторами усовершенствованной конструкции. Виброкавитатор обеспечивает кавитационную гомогенизацию суспензий водорослей с производительностью 0,75-1,0 м³ час. Предложенный технологический процесс переработки биомассы водорослей включает три основных этапа: этап накопления и подготовки суспензии водорослей; этап подготовки субстрата биомассы водорослей их гомогенизацией виброрезонансными кавитаторами; этап ферментации биогаза „метановым брожением“. Выход готового продукта, т.е. биогаза, благодаря увеличению виброкавитацией выделения из бактерий их внутриклеточного содержимого, увеличивается в 1,4 раза и достигает 33,0-34,5 м 3 биогаза из 1 тонны биомассы.

Научная новизна. Дополнение типовых технологических процессов переработки сине-зеленых водорослей этапом их гомогенизации виброкавитацией с конечной целью повышения выхода готового продукта авторами предложено впервые. Это решение обеспечивает более качественную дальнейшую ферментацию субстрата биомассы с повышением более чем на треть производительности образования биогаза. Обладает элементами научной новизны и впервые предложенная конструкция электромагнитного виброкавитатора резонансного действия. Специфическая форма его колеблющихся возбудителей кавитации предоставляет уникальную возможность качественной кавитационной обработки жидких субстанций повышенной, по сравнению с водой, плотности и вязкости. Именно это и позволяет возбуждать кавитационное поле высокой интенсивности в насыщенной водорослями жидкостной субстанции.

Практическая значимость. Заключается в совершенствовании технологического процесса ферментации биогаза из сине-зеленых водорослей. Для реализации кавитационной обработки биомассы предложена усовершенствованная конструкция виброкавитатора с учетом специфики кавитационной обработки жидкостей повышенных плотности и вязкости. Производительность виброкавитатора с поперечным сечением рабочей камеры 10 дюймов при обработке биомассы водорослей составляет 0,75-1,0 м³ /час. Этого достаточно для обеспечения двумя поочередно работающими виброкавитаторами безостановочной работы ферментационной камеры объемом $100 \mathrm{~m}^{3}$.

Ключевые слова: цианобактерии, биогаз, кавитация, гомогенизация, виброкавитатор, электромагнит

Recommended for publication by I. M. Petrushka, Doctor of Technical Sciences. The manuscript was submitted 20.02.19. 